\title{
ANALISIS PENGARUH FAKTOR-FAKTOR PERAMALAN TERHADAP GALAT, BIAYA, DAN KINERJA PENGIRIMAN PERUSAHAAN MANUFAKTUR MENGGUNAKAN METODE HIERARCHICAL REGRESSION
}

\author{
Wiwik Anggraeni, Retno Aulia Vinarti, Atikah Shafira Hatta \\ Jurusan Sistem Informasi, Fakultas Teknologi Informasi, Institut Teknologi Sepuluh Nopember \\ Kampus ITS, Sukolilo, Surabaya 60111 \\ Telp: (031) 5999944, Fax: (031) 5964965 \\ E-mail: wiwik@is.its.ac.id
}

\begin{abstract}
All manufacturing companies in need of an optimal production planning. In order to continue to survive, then manufacturing company seeks to optimize the entire activity in every sector to work as effective and efficient as possible, including on the production sector. One of the steps undertaken by the manufacturing company is making production planning which has minimum costs, including the cost of overtime (overtime cost) and the cost of inventories (inventory cost), but still be able to meet the demand. Demand forecasting activities are certainly needed in this case, however, the vast majority of manufacturing companies are not aware of the importance of accuracy of demand forecasting company. Demand forecasting is one of the few important input in the production planning process. If the result is not accurate forecasting, production plan to be not credible, because it will cause excess inventory or lost sales and can cause severe costs of manufacturing systems (Pamela, 2010). Forecasting accuracy is often considered a necessity due to the magnitude of forecasting error is usually a positive effect on the performance of the company's operations, particularly the cost of production and shipping. Hence the need to held evaluation of forecasting the demand made by the manufacturing company for the cost and performance of the delivery method using Hierarchical Regression. This final project will be able to see if there is the influence of the process variables with forecasting forecasting errors, and then do the forecasting error influence on cost and delivery performance. Thus, the smaller the forecasting errors are made, then the effective cost of production and shipping companies.
\end{abstract}

\section{Abstrak}

Perusahaan manufaktur membutuhkan perencanaan produksi yang optimal agar dapat terus bertahan. Oleh karena itu, perusahaan manufaktur berusaha mengoptimalkan seluruh kegiatan pada setiap sektornya untuk bekerja secara efektif dan efisien. Hal ini dimaksudkan agar perencanaan seluruh kegiatan yang dilakukan akan membutuhkan biaya minimum tanpa mengurangi kinerja perusahaan. salah satu cara yang dapat mendukung tujuan perusahaan tersebut adalah dengan melakukan perencanaan di awal. Perencanaan tersebut dapat dilakukan dengan menggunakan peramalan. Aktivitas peramalan sangat dibutuhkan namun sebagian besar perusahaan manufaktur tidak begitu sadar akan pentingnya akurasi peramalan dalam perusahaan. Penelitian ini akan menganalisis factor-faktor pada proses peramalan yang dapat meningkatkan tingkat akurasi hasil peramalan serta factor-faktor yang dapat meningkatkan kinerja operasional perusahaan. Metode yang digunakan adalah Hierarchical Regression. Hierarchical Regression dipilih karena Hierarchical Regression tidak hanya melihat satu faktor saja, tetapi beberapa faktor yang berpengaruh sehingga dapat dilakukan analisis secara detil..

Kata kunci: perencanaan produksi, permintaan, peramalan, galat, hierarchical regression.

\section{PENDAHULUAN}

Peramalan permintaan merupakan masalah penting untuk perusahaan manufaktur. Beberapa proses pengambilan keputusan memerlukan perkiraan yang akurat untuk memilih tindakan yang tepat dan relevan untuk perencanaan produksi, penganggaran pejualan, peluncuran produk baru, perencanaan promosi, dan lain-lain. Hal ini merupakan salah satu faktor yang membantu produksi menjadi lebih efisien karena dalam merencanakan produksi diperlukan prediksi jumlah permintaan yang cukup akurat, sehingga biaya yang terjadi dapat diminimumkan. Perusahaan manufaktur membutuhkan perencanaan produksi yang optimal. Hal ini sesuai dengan tingkat penjualan produk yang semakin dinamis seiring dengan permintaan pasar yang terjadi. Agar dapat terus bertahan, 
Anggraeni, dkk., Analisis Pengaruh Faktor-Faktor Peramalan terhadap Galat, Biaya, dan Kinerja..

maka perusahaan manufaktur berusaha mengoptimalisasi seluruh kegiatan pada setiap sektornya untuk bekerja secara efektif dan efisien, salah satunya sektor produksi. Salah satu langkah yang dilakukan oleh perusahaan manufaktur adalah dengan membuat perencanaan produksi yang memiliki biaya-biaya minimum, termasuk didalamnya biaya produksi langsung, biaya total produk dan biaya raw material. Aktifitas peramalan permintaan tentu dibutuhkan dalam hal ini, akan tetapi sebagian besar perusahaan manufacturing tidak begitu sadar akan pentingnya keakurasian peramalan permintaan perusahaan, sehingga pada bulan tertentu bisa saja terjadi overcost pada bagian produksi dan pengiriman yang tidak mereka sadari.

Meningkatnya proses peramalan sering dianggap kritis untuk mendapatkan perkiraan yang lebih akurat. Akurasi peramalan sering dianggap suatu keharusan karena besarnya galat biasanya berpengaruh positif terhadap kinerja operasional perusahaan, terutama biaya produksi dan pengiriman. Ketidakakuratan dalam peramalan dapat berarti kelebihan persediaan atau kehilangan penjualan dan dapat menyebabkan dampak biaya yang parah pada sistem manufaktur. Mengingat peramalan memegang peranan sangat penting maka perlu dilakukan analisis faktor-faktor peramalan yang diperkirakan dapat meningkatkan kinerja operasional perusahaan manufaktur. Metode yang digunakan adalah Hierarchical Regression. Metode Hierarchical Regression dipilih karena Hierarchical Regression tidak hanya melihat satu faktor saja namun dapat melibatkan beberapa faktor yang berpengaruh sehingga dapat diharapkan dapat mendapatkan hasil yang lebih detil.

Penelitian ini akan menganalisis apakah terdapat pengaruh dari faktor-faktor peramalan terhadap galat, pengaruh faktor peramalan terhadap biaya serta kinerja pengiriman. Dari hasil penelitian ini diharapkan dapat diketahui apakah terdapat faktor-faktor peramalan yang dapat meningkatkan kinerja operasional perusahaan selain meningkatkan akurasi dari sebuah peramalan.

\section{METODOLOGI}

Langkah-langkah yang digunakan dalam penelitian ini dapat dilihat pada Gambar 1 .

\subsection{Pengolahan Data}

Data yang diambil pada penelitian ini adalah kumpulan data dari Global Manufacturing Research Group (GMRG). Penelitian ini menggunakan 3 kelompok sampel data yaitu HR, JP, dan US.

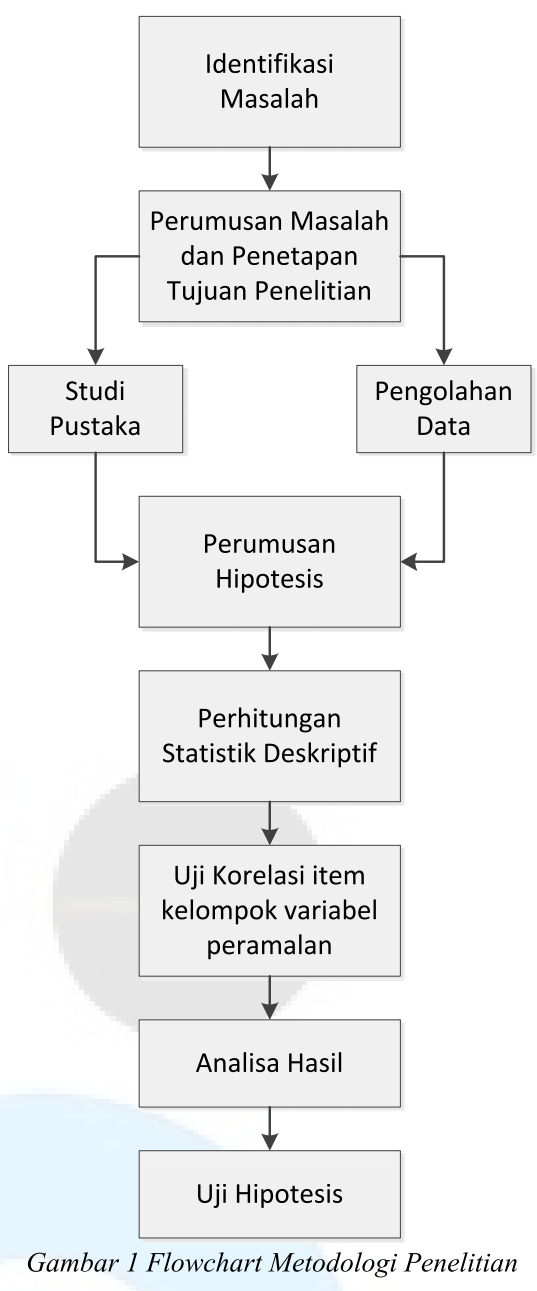

Pada data tersebut kemudian dilakukan pengelompokan factor-faktornya beserta pengkodeannya. Hasil pengelompokkan dapat dilihat pada Tabel 1.

Tabel 1 Pemetaan Data

\begin{tabular}{lll}
\hline \multicolumn{1}{c}{ Faktor } & \multicolumn{1}{c}{ Item } & Variabel \\
\hline $\begin{array}{l}\text { Teknik } \\
\text { Peramalan }\end{array}$ & $\begin{array}{l}\text { Model time series } \\
\text { kuantitatif } \\
\text { Model kausal } \\
\text { kuantutatif } \\
\text { Model Kualitatif } \\
\text { (Management }\end{array}$ & TCHS1 \\
& TCHS2 \\
opinion) & TCHS3 \\
Kenggu- & $\begin{array}{l}\text { Kondisi ekonomi } \\
\text { sekarang }\end{array}$ & SUBOBJ1 \\
Informasi & $\begin{array}{l}\text { Perencanaan } \\
\text { penjualan kustomer }\end{array}$ & SUBOBJ2 \\
& $\begin{array}{l}\text { Informasi supplier } \\
\text { Penelitian pasar }\end{array}$ & SUBOBJ3 \\
& $\begin{array}{l}\text { PUBOBapan penjualan } \\
\text { dan keuangan }\end{array}$ & FRCSTUS1 \\
Peran & $\begin{array}{l}\text { Perencanaan produksi } \\
\text { Peramalan }\end{array}$ & FRCSTUS2 \\
& $\begin{array}{l}\text { Pengembangan } \\
\text { produk baru }\end{array}$ & FRCSTUS7 \\
& $\begin{array}{l}\text { Perencanaan } \\
\text { peralatan }\end{array}$ & FRCSTUS9 \\
\hline
\end{tabular}




\begin{tabular}{cll}
\hline Faktor & \multicolumn{1}{c}{ Item } & Variabel \\
\hline & $\begin{array}{l}\text { Untuk produk } \\
\text { individu, berapa } \\
\text { persen galat pada dua } \\
\text { bulan ke depan. } \\
\text { Untuk total } \\
\text { penjualan, berapa } \\
\text { persen galat pada } 24 \\
\text { bulan ke depan }\end{array}$ & ERR1 \\
& $\begin{array}{l}\text { Biaya langsung } \\
\text { manufaktur }\end{array}$ & COMPUSE1 \\
& $\begin{array}{l}\text { Biaya total produk } \\
\text { Biaya raw material }\end{array}$ & COMPUSE2 \\
& $\begin{array}{l}\text { Kecepatan } \\
\text { pemenuhan order }\end{array}$ & PGRMS8 \\
Biaya & $\begin{array}{l}\text { Kecepatan } \\
\text { pengiriman }\end{array}$ & PGRMS9 \\
Kinerja \\
$\begin{array}{l}\text { Pengiri- } \\
\text { man }\end{array}$
\end{tabular}

\subsection{Perhitungan Statistik Deskriptif}

Masing-masing perusahaan memiliki perbedaan pada aktivitas peramalannya, kita dapat melihat dari statistik deskriptif aktivitas peramalan yang dilaksanakan oleh masing-masing perusahaan. Disini dilakukan perhitungan mean, median, standar deviasi dan kuartil

\subsection{Uji Korelasi Item Variabel Peramalan}

Dalam tahap ini, dilakukan analisis tiga faktor yang menjadi karakteristik proses peramalan, yaitu tingkat penggunaan teknik peramalan, tingkat penggunaan informasi dari sumber yang berbeda dan peran peramalan dalam pengambilan keputusan. Setiap kelompok faktor peramalan memiliki beberapa item yang setiap itemnya akan dihitung korelasinya. Dalam tahap ini akan ditemukan nilai koefisien korelasi Pearson dari variabel, eigen-value dari matriks, dan nilai tsquare dari data. Selain uji korelasi data, dihitung pula nilai varians dan nilai kepercayaan data dengan menggunakan Cronbach aplha.

\subsection{Uji Korelasi Semua Variabel Peramalan}

Pertama akan dilakukan perhitungan range permintaan yang diukur dan dipertimbangkan sebagai variabel kontrol yang berpengaruh terhadap korelasi. Hal ini dilakukan dengan mengacu pada penelitian yang dilakukan oleh Frohlich and Westbrook (2002) dan Zhu and Kraemer (2002) dan Zhu et al. (2004). Setelah itu dilakukan uji korelasi untuk semua factor peramalan. Pada penelitian ini penulis juga mempertimbangkan ukuran perusahaan (size), diukur dari logaritma natural jumlah karyawan sebagai variabel kontrol.

\subsection{Perhitungan Regresi}

Analisa regresi dilakukan pada masing-masing faktor peramalan yaitu teknik, informasi, dan peran peramalan. Pada analisa ini, ukuran perusahaan (size) dan range menjadi kontrol variabel, sementara galat menjadi variabel dependen. Penggunaan regresi linear merujuk pada referensi utama yang digunakan (Pamela, 2010). Pada referensi tersebut telah terbukti bahwa semua data yang digunakan bersifat linear sehingga digunakan metode regresi linear dibandingkan dengan regresi non-linear.

\subsection{Perhitungan Hierarchical Regression}

Diagram alir proses dalam metode hierarchical regression dapat dilihat pada Gambar 2.

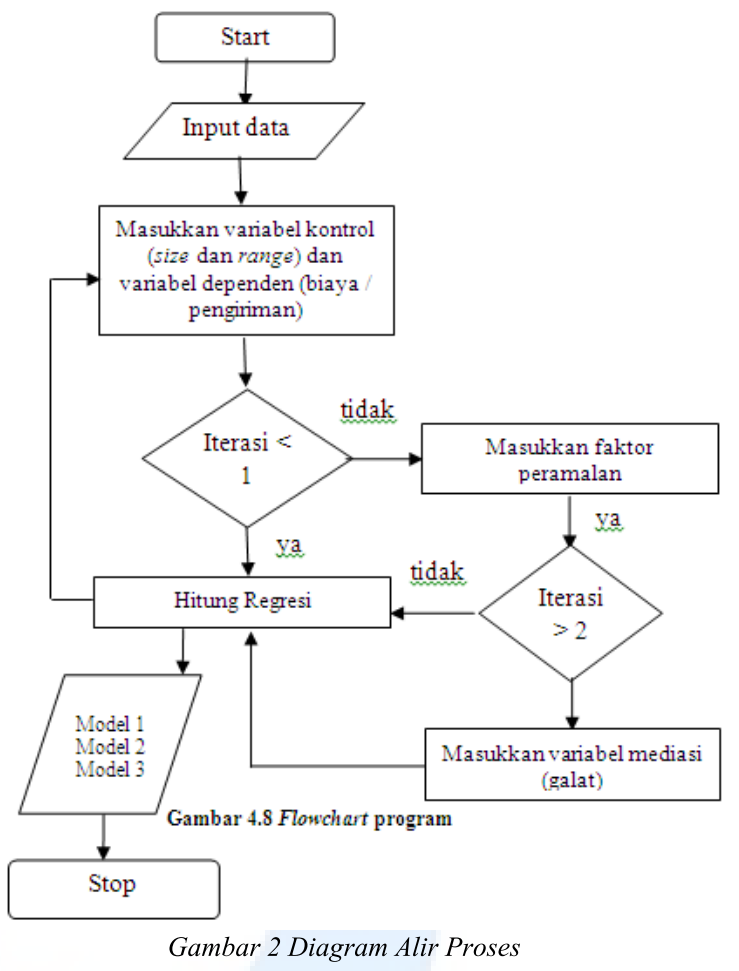

Pertama, variabel kontrol (range dan size) dipertimbangkan pada model regresi dengan biaya (atau pengiriman) sebagai variabel dependen. Selanjutnya dilakukan generalisasi model regresi linier dan berikutnya diuji apakah model secara signifikan lebih baik. Setelah model $\mathrm{x}$ telah diperoleh hasilnya, selanjutnya satu faktor peramalan dimasukkan kedalam model. Berikutnya faktor galat dimasukkan pada model regresi. Pembuatan model serta validasi model menggunakan cara yang diperkenalkan oleh Wampold \& Freund serta Baron \& Kenny.

\subsection{Perumusan Hipotesis}

Hipotesis yang digunakan dalam penelitian ini diambil dari jurnal "The Role of the forecasting process in improving forecast accuracy and operational performance" (Kalchschmidt, 2010). 
Anggraeni, dkk., Analisis Pengaruh Faktor-Faktor Peramalan terhadap Galat, Biaya, dan Kinerja..

\subsection{Analisa Hasil}

Analisis hasil meliputi analisis pengaruh dari faktor peramalan terhadap galat, analisis pengaruh factor peramalan terhadap biaya dan analisis pengaruh factor peramalan terhadap kinerja pengiriman.

\section{HASIL dan PEMBAHASAN}

Pada bab ini akan dijelaskan mengenai perhitungan statistik deskriptif untuk mengetahui karakteristik data, uji korelasi data, dan analisa dampak dari faktor peramalan terhadap galat serta pengaruhnya terhadap biaya dan kinerja pengiriman menggunakan metode hierarchical regression yang selanjutnya digunakan untuk uji hipotesis.

\subsection{Hasil Statistik Deskriptif}

Terdapat 378 data perusahaan manufaktur dari total 3 negara. Sample data dibagi berdasarkan masing-masing ukuran perusahaan dan sektor industri yang berkaitan dengan manufaktur dan industri perakitan. Sample terdiri dari perusahaan menengah tetapi juga merepresentasikan perusahaan kecil dan besar. Masing-masing contoh perusahaan memiliki perbedaan pada aktivitas peramalannya. Sampling serta hasil statistic deskriptif dapat dilihat pada Tabel 2 dan Tabel 3.

Tabel 2 Distribusi sampling ukuran perusahaan

\begin{tabular}{lrr}
\hline \multicolumn{1}{c}{ Ukuran perusahaan } & Frekuensi & \multicolumn{1}{c}{$\%$} \\
\hline Kecil $(<51$ pekerja) & 99 & 28.9 \\
Sedang $(51-250$ pekerja) & 127 & 37 \\
Besar $(>250$ pekerja) & 112 & 32.7 \\
\hline
\end{tabular}

Tabel 3 Statistik deskriptif dari aktivitas peramalan

\begin{tabular}{lccccc}
\hline & Mean & $\begin{array}{c}\text { Q } \\
\mathbf{2}\end{array}$ & $\begin{array}{c}\text { Std. } \\
\text { Devias } \\
\text { i }\end{array}$ & Q1 & $\begin{array}{c}\text { Q } \\
\mathbf{3}\end{array}$ \\
\hline $\begin{array}{l}\text { Rentang } \\
\text { waktu (bulan) }\end{array}$ & 7.95 & 6 & 8.43 & 3 & 12 \\
$\begin{array}{l}\text { Jml. } \\
\text { modifikasi } \\
\text { peramalan }\end{array}$ & 9.43 & 4 & 3.13 & 2 & 12 \\
\hline
\end{tabular}

Dapat diketahui bahwa sebagian besar perusahaan melakukan aktivitas peramalan ratarata kurang dari satu tahun (7.95 bulan). Beberapa perusahaan memperbarui (update) data peramalan mereka kurang dari satu kali per bulan (12 kali per tahun). Namun, hasil dari standar deviasi tinggi. Hal ini menunjukkan sampel memiliki nilai penyebaran data yang tinggi oleh karena itu hasil yang disajikan dalam bagian berikutnya tidak boleh menyimpang dari aktivitas peramalan.

\subsection{Hasil Uji Korelasi Item pada Kelompok Variabel Faktor Peramalan}

Hasil uji korelasi item menyatakan bahwa kesemua item tersebut berkorelasi satu sama lain (signifikan pada level 0.01) hal ini menun-jukkan bahwa item-item dari faktor tingkat penggunaan teknik peramalan memiliki hubungan yang erat. Tingkat kepercayaan data sangat tinggi dilihat dari hasil Cronbach alpha diatas 0.6. Analisis principal component menunjukkan bahwa semua Factor Load lebih besar dari 0.70 (Gefen dkk, 2000). Dengan demikian, semua faktor dapat dimasukkan pada analisis regresi. Hasil detil ada di Tabel 4.

Tabel 4 Ringkasan hasil uji korelasi item

\begin{tabular}{lrrrrrr}
\hline \multicolumn{1}{c}{ Uji Korelasi Item } & $\begin{array}{c}\text { Min } \\
\mathbf{r}\end{array}$ & $\begin{array}{c}\text { Max } \\
\mathbf{r}\end{array}$ & $\begin{array}{c}\text { Min } \\
\text { Loading } \\
\text { Factor }\end{array}$ & $\begin{array}{c}\text { Max } \\
\text { Loading } \\
\text { Factor }\end{array}$ & $\begin{array}{c}\text { \% } \\
\text { Varians }\end{array}$ & $\begin{array}{c}\text { Cronbach } \\
\text { Alpha }\end{array}$ \\
\hline $\begin{array}{l}\text { Tingkat Penggunaan Teknik } \\
\text { Peramalan (TCHS1, TCHS2, }\end{array}$ & & & & & & \\
TCHS3) & 0.711 & 0.781 & 0.904 & 0.932 & 83.629 & 0.902 \\
HR & 0.783 & 0.818 & 0.92 & 0.934 & 86.358 & 0.921 \\
JP & 0.75 & 0.831 & 0.906 & 0.938 & 85.584 & 0.916 \\
US & 0.627 & 0.792 & 0.862 & 0.932 & 80.584 & 0.88 \\
Tingkat Penggunaan Informasi & & & & & & 0.932 \\
(SUBOBJ1, SUBOBJ2, SUBOBJ3, & & & & & & 0.881 \\
SUBOBJ4) & 0.741 & 0.82 & 0.894 & 0.924 & 83.22 & 0.955 \\
HR & 0.626 & 0.75 & 0.835 & 0.897 & 74.14 & 0.949 \\
JP & 0.73 & 0.906 & 0.906 & 0.963 & 88.167 & \\
US & 0.798 & 0.832 & 0.913 & 0.951 & 86.996 & \\
Tingkat Pengambilan Keputusan & & & & & & 0.908 \\
(FRCSTUS1, FRCSTUS2, & & & & & & 0.832 \\
\hline FRCSTUS7, FRCSTUS9) & 0.652 & 0.805 & 0.855 & 0.912 & 78.801 & \\
HR & 0.498 & 0.699 & 0.777 & 0.965 & 68.652 & \\
\hline
\end{tabular}




\begin{tabular}{lrrrrrr}
\hline \multicolumn{1}{c}{ Uji Korelasi Item } & \multicolumn{1}{c}{$\begin{array}{c}\text { Min } \\
\mathbf{r}\end{array}$} & $\begin{array}{c}\text { Max } \\
\mathbf{r}\end{array}$ & $\begin{array}{c}\text { Min } \\
\text { Loading } \\
\text { Factor }\end{array}$ & $\begin{array}{c}\text { Max } \\
\text { Loading } \\
\text { Factor }\end{array}$ & $\begin{array}{c}\text { \% } \\
\text { Varians }\end{array}$ & $\begin{array}{c}\text { Cronbach } \\
\text { Alpha }\end{array}$ \\
\hline JP & 0.62 & 0.835 & 0.855 & 0.914 & 78.802 & 0.909 \\
US & 0.851 & 0.911 & 0.94 & 0.966 & 90.194 & 0.963 \\
Galat (ERR11, ERR22) & 0.513 & 0.513 & 0.87 & 0.87 & 78.801 & 0.678 \\
HR & 0.817 & 0.817 & 0.953 & 0.953 & 90.829 & 0.896 \\
JP & 0.722 & 0.722 & 0.928 & 0.928 & 86.103 & 0.833 \\
US & 0.485 & 0.485 & 0.862 & 0.862 & 74.273 & 0.653 \\
Biaya (COMPUSE1, COMPUSE2, & & & & & & \\
COMPUSE3) & 0.617 & 0.787 & 0.853 & 0.927 & 79.849 & 0.87 \\
HR & 0.733 & 0.847 & 0.911 & 0.955 & 86.538 & 0.922 \\
JP & 0.584 & 0.801 & 0.836 & 0.931 & 79.113 & 0.863 \\
US & 0.414 & 0.694 & 0.788 & 0.919 & 71.956 & 0.793 \\
Kinerja Pengiriman (PRGMS8, & & & & & & \\
PRGMS9, PRGMS10) & 0.656 & 0.732 & 0.872 & 0.905 & 79.28 & 0.867 \\
HR & 0.653 & 0.843 & 0.857 & 0.938 & 82.817 & 0.888 \\
JP & 0.57 & 0.841 & 0.816 & 0.938 & 79.18 & 0.866 \\
US & 0.479 & 0.711 & 0.718 & 0.898 & 69.834 & 0.746 \\
\hline
\end{tabular}

3.3 Uji Korelasi Semua Variabel Peramalan Tabel 5 merupakan hasil dari uji korelasi. Tabel tersebut menunjukkan semua variabel peramalan memiliki hubungan, terdapat hubu-ngan positif dan hubungan negatif. Hubungan antara faktor teknik peramalan dan semua variabel adalah positif kecuali pada galat, begitu pula pada faktor informasi dan peran peramalan terhadap galat yang berhubungan negatif. Faktor informasi juga memiliki hubungan negatif terhadap ukuran perusahaan. Galat memiliki hubungan negatif terhadap semua faktor. Biaya memiliki hubungan negatif terhadap range permintaan, sementara kinerja pengiriman, uku-ran perusahaan dan range permintaan memiliki hubungan positif terhadap semua variabel.

\subsection{Analisis Hasil}

Analisis hasil meliputi analisis dampak dari faktor peramalan terhadap galat serta pengaruhnya terhadap biaya dan kinerja pengiriman.

Tabel 5 Hasil uji korelasi variabel peramalan pada 3 kelompok sampel

\begin{tabular}{|c|c|c|c|c|c|c|c|c|c|}
\hline & & Teknik & Informasi & Peran & Error & Biaya & Pengiriman & Size & Range \\
\hline \multirow[t]{4}{*}{ Teknik } & 1 & 1 & 0.4 & 0.55 & -0.06 & 0.21 & 0.12 & 0.05 & 0.13 \\
\hline & 2 & 1 & 0.32 & 0.71 & 0.22 & 0.13 & 0.01 & 0.08 & -0.11 \\
\hline & 3 & 1 & 0.49 & 0.86 & -0.14 & 0.37 & 0.86 & -0.02 & 0.11 \\
\hline & 4 & 1 & 0.37 & 0.57 & -0.14 & -0.06 & -0.08 & -0.02 & 0.11 \\
\hline \multirow{4}{*}{ Informasi } & 1 & & 1 & 0.56 & -0.06 & 0.2 & 0.11 & -0.1 & 0.05 \\
\hline & 2 & & 1 & 0.5 & 0.08 & 0.06 & -0.05 & 0.17 & -0.06 \\
\hline & 3 & & 1 & 0.73 & -0.21 & 0.29 & 0.73 & 0.06 & 0.01 \\
\hline & 4 & & 1 & 0.43 & 0.01 & 0.05 & -0.05 & -0.15 & 0.08 \\
\hline \multirow{4}{*}{ Peran } & 1 & & & 1 & -0.15 & 0.22 & 0.2 & 0.14 & 0.05 \\
\hline & 2 & & & 1 & 0.27 & 0.59 & 0.52 & 0.16 & -0.09 \\
\hline & 3 & & & 1 & -0.2 & 0.7 & 1 & 0.05 & 0 \\
\hline & 4 & & & 1 & -0.17 & 0.06 & -0.01 & 0.1 & 0.01 \\
\hline \multirow{4}{*}{ Error } & 1 & & & & 1 & -0.08 & -0.1 & -0.01 & -0.05 \\
\hline & 2 & & & & 1 & 0.06 & 0.23 & 0.09 & -0.08 \\
\hline & 3 & & & & 1 & -0.15 & -0.2 & -0.14 & 0.08 \\
\hline & 4 & & & & 1 & -0.05 & -0.06 & 0.05 & -0.16 \\
\hline Biaya & 1 & & & & & 1 & 0.32 & 0.18 & -0.07 \\
\hline
\end{tabular}


Anggraeni, dkk., Analisis Pengaruh Faktor-Faktor Peramalan terhadap Galat, Biaya, dan Kinerja..

\begin{tabular}{|c|c|c|c|c|}
\hline & & Teknik & formasi & Peran \\
\hline \multirow[b]{4}{*}{ Pengiriman } & 2 & & & \\
\hline & 3 & & & \\
\hline & 4 & & & \\
\hline & 1 & & & \\
\hline \multirow{7}{*}{ Size } & 2 & & & \\
\hline & 3 & & & \\
\hline & 4 & & & \\
\hline & 1 & & & \\
\hline & 2 & & & \\
\hline & 3 & & & \\
\hline & 4 & & & \\
\hline \multicolumn{5}{|c|}{$\begin{array}{l}\text { 3.5 Dampak dari faktor peramalan terhadap } \\
\text { galat }\end{array}$} \\
\hline \multicolumn{5}{|c|}{ Tabel 6 Hasil analisa regresi-standard coefficients } \\
\hline \multirow[t]{2}{*}{ Variable } & \multicolumn{4}{|c|}{ Galat } \\
\hline & Semua & Hungary & Jepang & AS \\
\hline Teknik & -0.243 & 1.5916 & -0.666 & -0.76 \\
\hline Informasi & -0.461 & 1.3628 & -0.564 & -0.103 \\
\hline Peran & -0.104 & 1.5937 & -0.603 & -0.317 \\
\hline
\end{tabular}

Dapat dilihat pada Tabel 6 bahwa terdapat hubungan yang negatif antara galat dengan teknik peramalan. Hal ini menunjukkan bahwa dengan hanya mengadopsi teknik peramalan saja tidak menjamin dapat meningkatkan akurasi dari sebuah peramalan. Akan tetapi Tabel 3 juga menunjukkan bahwa tidak terdapat hubungan yang negatif antara galat dengan teknik peramalan, galat dengan informasi, dan galat dengan peran. Tabel 2 menunjukkan bahwa faktor teknik peramalan secara signifikan berhubungan dengan galat, begitu juga dengan faktor sumber informasi dan peran peramalan dalam pengambilan keputusan (level signifikan $0.01)$.

Berikutnya dilakukan perhitungan hierarchical regression yang hasilnya disajikan pada Tabel 7 . Dari sini dapat dilihat bahwa semua faktor peramalan berhubungan secara signifikan dengan biaya dan pengiriman.

Tabel 7. Hasil hierarchical regression - informasi peramalan

\begin{tabular}{lcccc}
\hline \multirow{2}{*}{ Variabel } & \multicolumn{2}{c}{ Kinerja biaya } & \multicolumn{2}{c}{ Kinerja pengiriman } \\
& Model 2 & Model 3 & Model 2 & Model 3 \\
\hline Teknik & $.144^{* *}$ & $.142^{* *}$ & $.070^{* *}$ & $.067^{* *}$ \\
Error & & -0.01 & & -0.012 \\
Informasi & $.276^{* *}$ & $.271^{* *}$ & $.120^{* *}$ & $.114^{* *}$ \\
Error & & -0.01 & & -0.012 \\
\hline
\end{tabular}

\begin{tabular}{|c|c|c|c|c|}
\hline Peran & $.238 * *$ & $.230 * *$ & $.203 * *$ & $.192 * *$ \\
\hline Error & & -0.007 & & -0.009 \\
\hline
\end{tabular}

Hasil dari analisa hierarchical regression menunjukkan bahwa semua faktor peramalan berhubungan secara signifikan dengan biaya dan kinerja pengiriman. Disamping itu, pada analisa hierarchical regression yang direpresentasikan oleh model 3, galat tidak berhubungan secara signifikan. Hal ini menunjukkan bahwa keberadaan dari efek mediasi diluar galat tidak mendukung. Sementara terdapat efek signifikan langsung dari setiap faktor peramalan pada biaya dan kinerja pengiriman.

Dapat diketahui bahwa setiap faktor peramalan mempunyai efek langsung dan hubungan positif terhadap kinerja operasional (biaya dan kinerja pengiriman) yang mana tidak termediasi oleh galat. Berikutnya akan dilihat dampak langsung dan dampak mediasi dari factor peramalan terhadap biaya dan kinerja pengiriman di masing-masing kelompok sampel. Hasinya disajikan dalam table 8 sampai Table 9 berikut.

Tabel 8. Hasil hierarchical regression - teknik peramalan kelompok sampel HR

\begin{tabular}{lcccc}
\hline \multirow{2}{*}{ Variabel } & \multicolumn{2}{c}{ Kinerja biaya } & \multicolumn{2}{c}{ Kinerja pengiriman } \\
& Model 2 & Model 3 & Model 2 & Model 3 \\
\hline Teknik & $.075^{* *}$ & $.072^{* *}$ & $.007^{* *}$ & $-.029^{* *}$ \\
Error & & $.005^{* *}$ & & 0.006 \\
Informasi & $.004^{* *}$ & $.003^{* *}$ & $.007^{* *}$ & $.008^{* *}$ \\
Error & & $.001^{* *}$ & & 0.006 \\
Peran & $.879^{* *}$ & $.919^{* *}$ & $.896^{* *}$ & $.851^{* *}$ \\
Error & & -0.027 & & $.002^{* *}$ \\
\hline
\end{tabular}

Tabel 9 menunjukkan bahwa pada kelompok sampel HR semua faktor peramalan berhubungan secara langsung dan positif terhadap biaya dan kinerja pengiriman. 
Tabel 9. Hasil hierarchical regression - teknik peramalan kelompok sampel JP

\begin{tabular}{lrrrr}
\hline Variabel & \multicolumn{2}{c}{ Kinerja biaya } & \multicolumn{2}{c}{ Kinerja pengiriman } \\
& Model 2 & \multicolumn{1}{c}{ Model 3 } & \multicolumn{1}{c}{ Model 2 } & Model 3 \\
\hline Teknik & 0.291 & 0.283 & $.535^{* *}$ & $.528^{* *}$ \\
Error & & $-.001^{* *}$ & & $-.009 * *$ \\
Informasi & 0.343 & 0.327 & $.702^{* *}$ & $.681^{* *}$ \\
Error & & $-.010^{* *}$ & & $-.007^{* *}$ \\
Peran & 0.393 & 0.378 & $.343^{* *}$ & $.612^{* *}$ \\
Error & & $.010^{* *}$ & & $.193^{* *}$ \\
\hline
\end{tabular}

Tabel 9 menunjukkan bahwa pada kelompok sampel JP semua faktor peramalan berhubungan secara langsung dan positif terhadap biaya dan kinerja pengiriman

Tabel 10. Hasil hierarchical regression - teknik peramalan kelompok sampel US

\begin{tabular}{llclc}
\hline \multicolumn{1}{c}{ Variabel } & \multicolumn{2}{c}{ Kinerja biaya } & \multicolumn{2}{c}{ Kinerja pengiriman } \\
& Model 2 & Model 3 & Model 2 & Model 3 \\
\hline Teknik & $.024 * *$ & $.032 * *$ & $.039 * *$ & $.044^{* *}$ \\
Error & & $-.012^{* *}$ & & $-.007^{* *}$ \\
Informasi & $.134^{* *}$ & $.137^{* *}$ & $.026^{* *}$ & $.024 * *$ \\
Error & & $-.012^{* *}$ & & $-.006^{* *}$ \\
Peran & $.028^{* *}$ & $.012^{* *}$ & $.015^{* *}$ & $.024^{* *}$ \\
Error & & $.001 * *$ & & $-.006^{* *}$ \\
\hline
\end{tabular}

Tabel 10 menunjukkan bahwa pada kelompok sampel US semua faktor peramalan berhubungan secara langsung dan positif terhadap biaya dan kinerja pengiriman.

\subsection{Hasil Uji Hipotesis}

Hasil uji hipotesis untuk masing-masing hipotesis awal dapat dilihat pada Tabel berikut.

Tabel 11. Hasil uji hipotesis penggunaan teknik peramalan berhubungan negatif dengan galat

\begin{tabular}{lrrr}
\hline $\begin{array}{l}\text { H1 : Penggunaan } \\
\text { teknik peramalan } \\
\text { berhubungan } \\
\text { negatif dengan } \\
\text { galat. }\end{array}$ & HR & \multicolumn{1}{c}{ JP } & \multicolumn{1}{c}{ US } \\
\hline $\begin{array}{l}\text { Null Hypothesis } \\
\text { Level of }\end{array}$ & 0.3 & 0.3 & 0.3 \\
$\begin{array}{l}\text { Significance } \\
\text { Population Standard }\end{array}$ & 0.01 & 0.01 & 0.01 \\
$\begin{array}{l}\text { Deviation } \\
\text { Sample Size }\end{array}$ & 4.52 & 6.4805 & 5.9171 \\
$\begin{array}{l}\text { Sample Mean } \\
\text { Standard Error of } \\
\text { the Mean }\end{array}$ & 1.5916 & -0.6663 & -0.7598 \\
$\begin{array}{l}\text { Z Test Statistic } \\
\text { Two-Tail Test }\end{array}$ & 0.4011 & 0.6793 & 0.5251 \\
$\begin{array}{l}\text { Lower Critical } \\
\text { Value }\end{array}$ & 3.2203 & -1.4224 & -2.0184 \\
Upper Critical Value & 2.5758 & 2.5758 & 2.5758 \\
p-Value & 0.0013 & 0.1549 & 0.0435 \\
\hline
\end{tabular}

\begin{tabular}{cclc}
\hline $\begin{array}{c}\text { H1 : Penggunaan } \\
\text { teknik peramalan } \\
\text { berhubungan } \\
\text { negatif dengan } \\
\text { galat. }\end{array}$ & HR & JP & US \\
\hline & $\begin{array}{c}\text { Reject } \\
\text { the null } \\
\text { hypothes } \\
\text { is }\end{array}$ & $\begin{array}{l}\text { Do not } \\
\text { reject the } \\
\text { null } \\
\text { hypothes } \\
\text { is }\end{array}$ & $\begin{array}{c}\text { Do not } \\
\text { reject } \\
\text { the null } \\
\text { hypothe } \\
\text { sis }\end{array}$ \\
\hline
\end{tabular}

Tabel 11 menunjukkan bahwa untuk perusahaan dalam kelompok sampel HR, penggunaan teknik peramalan berhubungan positif dengan galat. Hal ini berarti bahwa penggunaan berbagai macam metode ternyata tidak terbukti memperkecil galat. Hal ini dimungkinkan karena pemilihan metode yang kurang tepat untuk data tertentu. Sedangkan untuk perusahaan dalam kelompok sampel yang lain menyatakan bahwa penggunaan metode peramalan dapat memperkecil galat.

Tabel 12. Hasil uji hipotesis penggunaan beberapa sumber informasi berhubungan negatif dengan galat

\begin{tabular}{|c|c|c|c|}
\hline $\begin{array}{c}\text { H2 : Penggunaan } \\
\text { beberapa sumber } \\
\text { informasi } \\
\text { berhubungan } \\
\text { negatif dengan } \\
\text { galat. } \\
\end{array}$ & HR & JP & US \\
\hline $\begin{array}{l}\text { Null Hypothesis } \\
\mathrm{m}=\end{array}$ & 0.3 & 0.3 & 0.3 \\
\hline $\begin{array}{l}\text { Level of } \\
\text { Significance }\end{array}$ & 0.01 & 0.01 & 0.01 \\
\hline $\begin{array}{l}\text { Population Standard } \\
\text { Deviation }\end{array}$ & 4.52 & 6.4805 & 5.9171 \\
\hline Sample Size & 127 & 91 & 127 \\
\hline Sample Mean & 1.3628 & -0.5639 & -0.10302 \\
\hline $\begin{array}{l}\text { Standard Error of } \\
\text { the Mean }\end{array}$ & 0.4011 & 0.6793 & 0.5251 \\
\hline $\begin{array}{l}\text { Z Test Statistic } \\
\text { Two-Tail Test }\end{array}$ & 2.6498 & -1.2717 & -0.7676 \\
\hline $\begin{array}{l}\text { Lower Critical } \\
\text { Value }\end{array}$ & -2.5758 & -2.5758 & -2.5758 \\
\hline $\begin{array}{l}\text { Upper Critical } \\
\text { Value }\end{array}$ & 2.5758 & 2.5758 & 2.5758 \\
\hline \multirow[t]{2}{*}{ p-Value } & 0.0081 & 0.2035 & 0.4427 \\
\hline & $\begin{array}{c}\text { Reject } \\
\text { the null } \\
\text { hypothes } \\
\text { is }\end{array}$ & $\begin{array}{l}\text { Do not } \\
\text { reject the } \\
\text { null } \\
\text { hypothes } \\
\text { is }\end{array}$ & $\begin{array}{l}\text { Do not } \\
\text { reject the } \\
\text { null } \\
\text { hypothes } \\
\text { is }\end{array}$ \\
\hline
\end{tabular}

Tabel 12 menunjukkan bahwa untuk perusahaan dalam kelompok sampel HR, peramalan dengan menggunakan berbagai macam informasi berhubungan positif dengan galat. Hal ini berarti semaikn banyak informasi yang dilibatkan dalam proses peramalan ternyata membuat galat semakin besar pula. Sedangkan untuk perusahaan dalam kelompok sampel yang lain menyatakan bahwa semakin banyak informasi yang dilibatkan maka galat yang didapatkan semakin kecil. 
Anggraeni, dkk., Analisis Pengaruh Faktor-Faktor Peramalan terhadap Galat, Biaya, dan Kinerja..

Tabel 13. Hasil uji hipotesis pengambilan keputusan berbasis peramalan berhubungan negatif dengan galat

\begin{tabular}{|c|c|c|c|}
\hline $\begin{array}{c}\text { H3 : Penggunaan } \\
\text { pengambilan } \\
\text { keputusan berbasis } \\
\text { peramalan } \\
\text { berhubungan negatif } \\
\text { dengan kesalahan } \\
\text { peramalan } \\
\end{array}$ & HR & $\mathbf{J P}$ & US \\
\hline $\begin{array}{l}\text { Null Hypothesis } \\
m=\end{array}$ & 0.3 & 0.3 & 0.3 \\
\hline Level of Significance & 0.01 & 0.01 & 0.01 \\
\hline $\begin{array}{l}\text { Population Standard } \\
\text { Deviation }\end{array}$ & 4.52 & 6.4805 & 5.9171 \\
\hline Sample Size & 127 & 91 & 127 \\
\hline Sample Mean & 1.5937 & -0.603 & -0.3171 \\
\hline $\begin{array}{l}\text { Standard Error of the } \\
\text { Mean }\end{array}$ & 0.4011 & 0.6793 & 0.5251 \\
\hline $\begin{array}{l}Z \text { Test Statistic } \\
\text { Two-Tail Test }\end{array}$ & 3.2255 & -1.3292 & -1.1753 \\
\hline Lower Critical Value & -2.5758 & -2.5758 & -2.5758 \\
\hline Upper Critical Value & 2.5758 & 2.5758 & 2.5758 \\
\hline $\mathrm{p}$-Value & $\begin{array}{c}0.0013 \\
\text { Tolak } \\
\text { Ho }\end{array}$ & $\begin{array}{c}0.1838 \\
\text { Terima } \\
\text { Ho }\end{array}$ & $\begin{array}{c}0.2399 \\
\text { Terima } \\
\text { Ho }\end{array}$ \\
\hline
\end{tabular}

Tabel 13 menunjukkan bahwa untuk perusahaan dalam kelompok sampel HR, penggunaan pengambilan keputusan berbasis peramalan berhubungan positif dengan galat. Hal ini berarti semakin banyak peramalan dilibatkan dalam pengambilan keputusan ternyata membuat galat semakin besar pula. Sedangkan untuk perusahaan dalam kelompok sampel yang lain menyatakan bahwa semakin banyak keputusan yang melibatkan peramalan maka galat yang didapatkan semakin kecil.

Tabel 14. Hasil uji hipotesis penggunaan peramalan berhubungan positif secara langsung dengan biaya

\begin{tabular}{lrrr}
\hline $\begin{array}{c}\text { H4 : Penggunaan } \\
\text { teknik peramalan } \\
\text { berhubungan positif } \\
\text { secara langsung } \\
\text { dengan biaya }\end{array}$ & \multicolumn{1}{c}{ HR } & \multicolumn{1}{c}{ JP } & \multicolumn{1}{c}{ US } \\
\hline $\begin{array}{l}\text { Null Hypothesis } \\
\text { Level of Significance }\end{array}$ & 0.3 & 0.3 & 0.3 \\
Population Standard & 0.01 & 0.01 & 0.01 \\
Deviation & 4.52 & 6.4805 & 5.9171 \\
Sample Size & 127 & 91 & 127 \\
Sample Mean & 0.072 & 0.283 & 0.032 \\
Standard Error of the & 0.4011 & 0.6793 & 0.5251 \\
Mean & -0.5685 & -0.025 & -0.5104 \\
Z Test Statistic & & & \\
Two-Tail Test & -2.5758 & -2.5758 & -2.5758 \\
Lower Critical Value & 2.5758 & 2.5758 & 2.5758 \\
Upper Critical Value & 0.5697 & 0.98 & 0.6098 \\
p-Value & Terima & Terima & Terima \\
& Ho & Ho & Ho \\
\hline & & &
\end{tabular}

Tabel 14 menunjukkan bahwa untuk perusahaan dalam semua kelompok sampel, semakin banyak penggunaan teknik peramalan maka biaya akan semakin besar pula, dan begitu juga sebaliknya .
Tabel 15. Hasil uji hipotesis penggunaan peramalan berhubungan positif secara langsung dengan kinerja pengiriman

\begin{tabular}{lrrr}
\hline $\begin{array}{c}\text { H4 : Penggunaan } \\
\text { teknik peramalan } \\
\text { berhubungan positif } \\
\text { secara langsung } \\
\text { dengan kinerja } \\
\text { pengiriman. }\end{array}$ & HR & JP & \multicolumn{1}{c}{ US } \\
\hline $\begin{array}{l}\text { Null Hypothesis } \\
\text { Level of Significance }\end{array}$ & 0.3 & 0.3 & 0.3 \\
Population Standard & 0.01 & 0.01 & 0.01 \\
Deviation & 4.52 & 6.4805 & 5.9171 \\
Sample Size & 127 & 91 & 127 \\
Sample Mean & 0.029 & 0.528 & 0.044 \\
Standard Error of the & 0.4011 & 0.6793 & 0.5251 \\
Mean Statistic & -0.6757 & 0.3356 & -0.4876 \\
Z Test Static & & & \\
Two-Tail Test & -2.5758 & -2.5758 & -2.5758 \\
Lower Critical Value & 2.5758 & 2.5758 & 2.5758 \\
Upper Critical Value & 0.4993 & 0.7372 & 0.6259 \\
p-Value & Terima & Terima & Terima \\
& Ho & Ho & Ho \\
\hline & & & \\
\hline
\end{tabular}

Tabel 12 menunjukkan bahwa untuk perusahaan dalam semua kelompok sampel, semakin banyak penggunaan teknik peramalan maka kinerja pengiriman akan semakin bagus pula, dan begitu juga sebaliknya.

Tabel 13. Hasil uji hipotesis penggunaan sumber informasi berhubungan positif secara langsung dengan biaya

\begin{tabular}{lrrr}
\hline $\begin{array}{c}\text { H5 : Penggunaan } \\
\text { sumber informasi } \\
\text { berhubungan positif } \\
\text { secara langsung } \\
\quad \text { dengan biaya }\end{array}$ & HR & \multicolumn{1}{c}{ JP } & \multicolumn{1}{c}{ US } \\
\hline $\begin{array}{l}\text { Null Hypothesis } \\
\text { Level of Significance }\end{array}$ & 0.3 & 0.3 & 0.3 \\
Population Standard & 0.01 & 0.01 & 0.01 \\
Deviation & 4.52 & 6.4805 & 5.9171 \\
Sample Size & 127 & 91 & 127 \\
Sample Mean & 0.003 & 0.327 & 0.137 \\
Standard Error of the & 0.4011 & 0.6793 & 0.5251 \\
Mean & -0.7405 & 0.0397 & -0.3104 \\
Z Test Statistic & & & \\
Two-Tail Test & -2.5758 & -2.5758 & -2.5758 \\
Lower Critical Value & 2.5758 & 2.5758 & 2.5758 \\
Upper Critical Value & 0.459 & 0.9683 & 0.7562 \\
p-Value & Terima & Terima & Terima \\
& Ho & Ho & Ho \\
\hline
\end{tabular}

Tabel 15 menunjukkan bahwa untuk perusahaan dalam semua kelompok sampel, penggunaan berbagai macam informasi dalam peramalan maka biaya akan semakin besar pula, dan begitu juga sebaliknya. 
Tabel 16. Hasil uji hipotesis penggunaan sumber informasi berhubungan positif secara langsung dengan kinerja pengiriman

\begin{tabular}{lrrr}
\hline $\begin{array}{c}\text { H5 : Penggunaan } \\
\text { sumber informasi } \\
\text { berhubungan positif } \\
\quad \text { secara langsung } \\
\text { dengan kinerja } \\
\quad \text { pengiriman. }\end{array}$ & HR & JP & \multicolumn{1}{c}{ US } \\
\hline $\begin{array}{l}\text { Null Hypothesis } \\
\text { Level of Significance }\end{array}$ & 0.3 & 0.3 & \\
Population Standard & 4.52 & 0.01 & 0.01 \\
Deviation & 127 & 9.4805 & 5.9171 \\
Sample Size & 0.008 & 0.681 & 0.024 \\
Sample Mean & 0.4011 & 0.6793 & 0.5251 \\
Standard Error of the & -0.728 & 0.5608 & -0.5257 \\
Mean & & & \\
Z Test Statistic & -2.5758 & -2.5758 & -2.5758 \\
Two-Tail Test & 2.5758 & 2.5758 & 2.5758 \\
Lower Critical Value & 0.4666 & 0.5749 & 0.5991 \\
Upper Critical Value & Terima & Terima & Terima \\
p-Value & Ho & Ho & Ho \\
\hline
\end{tabular}

Tabel 16 menunjukkan bahwa untuk perusahaan dalam semua kelompok sampel, semakin banyak penggunaan peramalan denagn melibatkan berbagai macam sumber informasi akan meningkatkan kinerja pengiriman, dan begitu juga sebaliknya.

Tabel 17. Hasil uji hipotesis penggunaan pengambilan keputusan berbasis peramalan berhubungan positif secara langsung dengan biaya

\begin{tabular}{lrrr}
\hline $\begin{array}{c}\text { H6 : Penggunaan } \\
\text { pengambilan } \\
\text { keputusan berbasis } \\
\text { peramalan }\end{array}$ & HR & JP & US \\
$\begin{array}{c}\text { berhubungan positif } \\
\text { secara langsung } \\
\text { dengan biaya }\end{array}$ & & & \\
\hline Null Hypothesis & & & \\
Level of Significance & 0.3 & 0.3 & 0.3 \\
Population Standard & 4.52 & 0.01 & 0.01 \\
Deviation & 127 & 91 & 5.9171 \\
Sample Size & 0.919 & 0.378 & 0.012 \\
Sample Mean & 0.4011 & 0.6793 & 0.5251 \\
Standard Error of the & 1.5433 & 0.1148 & -0.5485 \\
Mean & & & \\
Z Test Statistic & -2.5758 & -2.5758 & -2.5758 \\
Two-Tail Test & 2.5758 & 2.5758 & 2.5758 \\
Lower Critical Value & 0.1228 & 0.9086 & 0.5833 \\
Upper Critical Value & Terima & Terima & Terima \\
p-Value & Ho & Ho & Ho \\
\hline
\end{tabular}

Tabel 17 menunjukkan bahwa untuk perusahaan dalam semua kelompok sampel, penggunaan keputusan berbasis peramalan berhubungan positif secara langsung dengan biaya.
Tabel 18. Hasil uji hipotesis penggunaan pengambilan keputusan berbasis peramalan berhubungan positif secara langsung dengan kinerja pengiriman

\begin{tabular}{lrrr}
\hline $\begin{array}{c}\text { H6 : Penggunaan } \\
\text { pengambilan } \\
\text { keputusan berbasis } \\
\text { peramalan }\end{array}$ & & & \\
$\begin{array}{c}\text { berhubungan positif } \\
\text { secara langsung } \\
\text { dengan kinerja } \\
\text { pengiriman. }\end{array}$ & HR & JP & \multicolumn{1}{c}{ US } \\
\hline Null Hypothesis & & & \\
Level of Significance & 0.3 & 0.3 & 0.3 \\
Population Standard & 4.52 & 0.4805 & 5.9171 \\
Deviation & 127 & 91 & 127 \\
Sample Size & 0.851 & 0.612 & 0.024 \\
Sample Mean & 0.4011 & 0.6793 & 0.5251 \\
Standard Error of the & 1.3738 & 0.4593 & -0.5257 \\
Mean & & & \\
Z Test Statistic & -2.5758 & -2.5758 & -2.5758 \\
Two-Tail Test & 2.5758 & 2.5758 & 2.5758 \\
Lower Critical Value & 0.1695 & 0.646 & 0.5991 \\
Upper Critical Value & Terima & Terima & Terima \\
p-Value & Ho & Ho & Ho \\
\hline
\end{tabular}

Tabel 18 menunjukkan bahwa untuk perusahaan dalam semua kelompok sampel, semakin banyak penggunaan pengambilan keputusan berbasis peramalan akan meningkatkan kinerja pengiriman, dan begitu juga sebaliknya.

\section{SIMPULAN dan SARAN}

Kesimpulan yang didapatkan dari hasil evaluasi dampak faktor-faktor peramalan terhadap galat serta biaya dan kinerja pengiriman dengan data yang digunakan dalam penelitian ini, antara lain adalah

a. Penggunaan teknik peramalan dalam sebuah proses peramalan belum tentu menjamin dapat mengurangi galat dari sebuah peramalan. Hal ini dapat terjadi jika nilai standar koefisien regresi faktor-faktor peramalan memiliki nilai $>1$

b. Penggunaan beberapa sumber informasi pada proses peramalan belum tentu menjamin dapat mengurangi galat dari sebuah peramalan. Hal ini dapat terjadi jika nilai standar koefisien regresi variabelnya memiliki nilai $>1$

c. Pengambilan keputusan berbasis peramalan belum tentu menjamin dapat mengurangi galat dari sebuah peramalan. Hal ini dapat terjadi jika nilai standar koefisien regresi variabelnya memiliki nilai $>1$

d. Penggunaan teknik peramalan dalam sebuah proses peramalan dapat meningkatkan kinerja biaya dan kinerja pengiriman tanpa adanya pengaruh dari tingkat akurasi peramalan

e. Penggunaan beberapa sumber informasi dalam sebuah proses peramalan dapat meningkatkan kinerja biaya dan kinerja 
Anggraeni, dkk., Analisis Pengaruh Faktor-Faktor Peramalan terhadap Galat, Biaya, dan Kinerja..

pengiriman tanpa adanya pengaruh dari tingkat akurasi peramalan

f. Pengambilan keputusan berbasis peramalan dapat meningkatkan kinerja biaya dan kinerja pengiriman tanpa adanya pengaruh dari tingkat akurasi peramalan.

\section{DAFTAR RUJUKAN}

Armstrong, J. Scott, 2012. Illusions in Regression Analysis, International Journal of Forecasting (forthcoming).

Baron, R.M., Kenny, D.A., 1986. The moderator-mediator variable distinction in social psychological research: conceptual, strategic and statistical considera- tions. Journal of Personality and Social Psychology 51 (6), 1173-1182.

Cohen Jacob, Cohen Patricia, 1983. Applied multiple regression/correlation analysis for the behavioral sciences. L. Erbaum Associates.

Dergibson Siagian \& Sugiarto. 2002. Metode Statistika untuk Bisnis dan Ekonomi. Jakarta : PT Gramedia Pustaka Utama

Faisal, Sanapioh. 1982. Metodologi Penelitian Pendidikan, Surabaya : Usaha Nasional.

Friedenberg, Lisa, 1995. Psychological Testing, Design, Analysis and Use, Allyn and Bacon.

Frohlich, M.T., Westbrook, R., 2002. Demand chain management in manufacturing and services: web-based integration, drivers and performance. Journal of Operations Management 20 (4), 729-745. Gmrg.org

Guilford ,J.P., 1979. Psychometric Methods, Tata McGraw-Hill Publishing Company Limited.

Guilford, J.P. 1956. Fundamental Statistics in Psychology and Education. New York: McGraw Hill. 145.

Herbig, P., Milewicz, J., Golden, J.E., 1994. Differences in forecasting behaviour between industrial product firms and consumer product firms. Journal of Business and Industrial Marketing 9, 60-69.

MacKinnon, D. P.; Lockwood, C. M. 2003. Advances in statistical methods for substance abuse prevention research. Prevention Science (3). 155-171.

Mentzer, J.T., Bienstock, C., 1998. Sales Forecasting Management. Sage Publications, London.

Moon, M.A., Mentzer, J.T., Smith, C.D., 2003. Conducting a sales forecasting audit. International Journal of Forecasting 19, 525.

Pamela Danese, Matteo Kalchschmidt, 2011. The Role of the forecasting process in improving forecast accuracy and operational performance, International Journal of Production Economics 131. 204-214.

Ronald E.Walpole. 1993. Pengantar Statistika. Jakarta : PT Gramedia Pustaka Utama.

Sanders, N.R., Manrodt, K.B., 2003. The efficacy of using judgmental versus quantitative forecasting methods in practice. Omega 31, 511-522.

Sobel, M.E., 1982. Asymptotic confidence intervals for indirect effects in structural equation models. Sociological Methodology 13 (1), 290-321.

Wampold, B.E., Freund, R.D., 1987. Use of multiple regression in counseling psychology research: a flexible data-analytic strategy. Journal of Counseling Psychology 34 (4), 372-382.

Winklhofer, H.M., Diamantopoulos, A., 2002. Managerial evaluation of sales forecasting effectiveness: a MIMIC modeling approach. International Journal of Research in Marketing 19 (2), 151-166. 